\title{
APPLICATION OF NATURAL ENVIRONMENT APPROACHES TO IMPROVE SCIENCE PROCESS SKILLS IN ELEMENTARY SCHOOL STUDENTS
}

\section{Laksmi Evasufi Widi Fajari, Joharman, Moh Salimi}

Universitas Sebelas Maret

evasufilaksmi123@gmail.com

\section{Article History}

accepted 09/07/2018

approved 01/08/2018

published 17/09/2018

Keywords

science process skill, PLAS

\begin{abstract}
The purpose of this research is to describe the implementation of Natural Environment Approach (PLAS) to improve the science process skill in elementary school students. This classroom action research is a collaborative study conducted by teachers and prospective teachers. The subjects of this study were teachers and students of class $V$. The results showed that the application of PLAS can improve the science process skill through the steps of: (1) determining the learning objectives, tools and instruments needed, and instructional activities, (2) the students are divided into several groups, (4) investigating and observing objects, discussing task sheets, and recording information, (5) reporting findings, conclusions and evaluations of learning.
\end{abstract}

Social, Humanities, and Education Studies (SHEs): Conference Series

p-ISSN 2620-9284 https://jurnal.uns.ac.id/shes e-ISSN 2620-9292 


\section{PENDAHULUAN}

IPA adalah salah satu mata pelajaran yang diajarkan di sekolah dasar. IPA merupakan ilmu dasar yang berhubungan dengan kehidupan manusia dan lingkungan sekitarnya. Pendidikan IPA di sekolah dasar diharapkan dapat menjadi wahana bagi peserta didik untuk mempelajari diri sendiri dan alam sekitar, serta prospek pengembangan lebih lanjut dalam menerapkannya dalam kehidupan sehari-hari (Permendiknas Nomor 22 Tahun 2006 tentang Standar Isi untuk Satuan Pendidikan Dasar dan Menengah, 2006: 484). Menurut Samatowa (2010: 3), IPA merupakan ilmu yang berhubungan dengan gejala alam dan kebendaan yang sistematis yang tersusun secara teratur, berlaku umum yang berupa kumpulan dari hasil observasi dan eksperimen secara sistematis atau teratur. Pendidikan IPA diarahkan untuk mencari tahu dan berbuat sehingga dapat membelajarkan siswa untuk memperoleh pemahaman yang lebih mendalam tentang lingkungan alam sekitar. Untuk itu pembelajaran IPA di sekolah dasar didesain agar siswa mengalami proses, bukan sekedar duduk manis menerima sekumpulan pengetahuan dari guru. Oleh karena itu dalam proses pembelajaran IPA selalu menekankan implementasi hakikat IPA. Hakikat IPA meliputi hakikat IPA sebagai produk, proses dan sikap. Pada penelitian ini akan dibatasi pada aspek keterampilan proses sains (KPS). Hakikat IPA sebagai proses memberikan gambaran bahwa IPA merupakan proses penemuan untuk menyusun pengetahuan yang meliputi: observasi, eksperimen, penyimpulan, dan lain-lain.

Semiawan (Isnanto, 2016: 2.757) mengemukakan bahwa dengan mengembangkan keterampilan-keterampilan proses IPA, siswa akan mampu menemukan dan mengembangkan sendiri fakta dan konsep serta menumbuhkan dan mengembangkan sikap dan nilai yang dituntut. Dengan demikian keterampilanketerampilan itu menjadi roda penggerak penemuan dan pengembangan fakta dan konsep serta penumbuhan dan pengembangan sikap dan nilai.

Namun, untuk mewujudkan pembelajaran IPA yang dapat mengembangkan keterampilan proses sangatlah tidak mudah. Berdasarkan hasil observasi di SDN 2 Karangreja, peneliti menemukan bahwa proses pembelajaran IPA di kelas V SDN 2 Karangreja: (1) sebagian besar masih dilaksanakan di dalam kelas, (2) hanya sebagian kecil materi yang disajikan dengan pengamatan langsung sehingga siswa kurang diberi peluang untuk mengembangkan keterampilan proses, serta (3) siswa kurang terlibat karena diposisikan sebagai pendengar. Hal di atas diduga disebabkan karena: (1) pembelajaran belum menggunakan sumber belajar yang familier bagi siswa, (2) pembelajaran belum mengoptimalkan pemanfaatan lingkungan alam sekitar dalam proses pembelajaran IPA, serta (3) pembelajaran masih dominan menggunakan metode ceramah dengan media gambar yang masih terbatas di ruangan kelas.

Melalui pengembangan keterampilan proses dalam pembelajaran IPA, siswa diharapkan lebih mudah menyerap dan memahami konsep IPA yang disampaikan, ini dikarenakan siswa diberikan kesempatan untuk bekerja dan langsung mengamati objek di lingkungan alam sekitarnya, bukan hanya sekedar mendengarkan penjelasan tentang IPA. Melalui kesempatan tersebut akan memberikan pengalaman nyata kepada siswa yang selain dapat membantunya memahami konsep tentang IPA, tetapi juga akan menjadi bekal dikehidupannya dalam memahami lingkungannya. Sehingga dengan penerapan pendekatan keterampilan proses diharapkan dapat memberikan kesempatan kepada siswa untuk sepenuhnya mengembangkan keterampilan proses sains.

Berdasarkan masalah tersebut, maka dalam pembelajaran IPA perlu adanya perbaikan pembelajaran. Salah satu solusi pembelajaran yaitu pembelajaran yang dapat memfasilitasi siswa untuk belajar secara aktif dan dapat mengembangkan keterampilan proses IPA. Pendekatan pembelajaran dengan memanfaatkan fasilitasfasilitas yang ada lingkungan alam sekitar serta menyediakan bahan-bahan pelajaran langsung yang memungkinkan siswa melakukan pengamatan langsung secara aktif 
dan memperoleh pemahaman yang lebih mendalam adalah Pendekatan Lingkungan Alam Sekitar (PLAS). PLAS adalah pendekatan yang mengupayakan pengembangan kurikulum sekolah dengan mengikutsertakan segala fasilitas yang ada di lingkungan alam sekitar sebagai sumber belajar (Barlia, 2006:2).

Berdasarkan uraian di atas, dapat dirumuskan masalah yaitu: (1) bagaimana konsep PLAS?; (2) bagaimana konsep keterampilan proses?; dan (3) bagaimana penerapan PLAS untuk meningkatkan keterampilan proses IPA pada siswa sekolah dasar?.

\section{METODE}

Penelitian ini dilaksanakan di SDN 2 Karangreja yang berlangsung dari bulan Agustus sampai Desember 2017. Subjek penelitian ini adalah guru dan siswa kelas V yang 21 siswa terdiri dari 12 siswa laki-laki dan 9 siswa perempuan

Data pada penelitian ini yaitu data mengenai penerapan PLAS pada pembelajaran IPA pada materi penyesuaian makhluk hidup. Adapun teknik pengumpulan data yang digunakan adalah observasi dan wawancara.

Teknik uji validitas data pada penelitian ini menggunakan teknik triangulasi, yaitu triangulasi teknik dan sumber. Triangulasi teknik yang digunakan, yaitu observasi, dan wawancara. Adapun triangulasi sumber yang digunakan, yaitu siswa dan guru. Teknik analisis data yang digunakan dalam penelitian ini yaitu analisis kualitatif deskriptif yang meliputi tiga langkah, yaitu reduksi data, penyajian data, dan penarikan kesimpulan. Adapun prosedur penelitian ini menggunakan model penelitian tindakan kelas yang terdiri dari empat tahapan, yaitu (1) perencanaan, (2) pelaksanaan, (3) pengamatan, (4) refleksi.

\section{A. Konsep PLAS}

\section{HASIL DAN PEMBAHASAN}

Barlia (2006: 2) mengemukakan bahwa proses belajar mengajar dengan mengaplikasikan PLAS adalah upaya pengembangan kurikulum sekolah yang ada, dengan mengikutsertakan segala fasilitas yang ada di lingkungan alam sekitar sebagai sumber belajar. Mengajar dengan PLAS dapat didefinisikan sebagai menggunakan atau memanfaatkan fasilitas-fasilitas yang ada dilingkungan alam sekitar sekolah, sebagai laboratorium untuk belajar.

Mengajar dengan pendekatan lingkungan alam sekitar dapat dikenal juga dengan istilah mengajar di luar kelas. Mengajar di luar kelas dipahami sebagai suatu kegiatan menyampaikan pelajaran di luar kelas, sehingga kegiatan belajar mengajar berlangsung di alam bebas (Vera, 2012: 17). Hal ini sejalan dengan penelitian yang dilakukan oleh Gilchrist, dkk. (2016: 6) yang mengatakan bahwa "Outdoor learning offer different types of learning and experience, there is widespread agreement that pupils can derive a range of benefits that include a healthier, more self- and environmentally-aware life for children and young people". Maksudnya yaitu pembelajaran di luar ruangan menawarkan berbagai tipe belajar dan pengalaman, ada banyak kesepakatan bahwa siswa dapat memperoleh berbagai manfaat yang mencakup kehidupan yang lebih sehat, lebih mandiri dan berwawasan lingkungan bagi anak-anak dan remaja.

Dari berbagai istilah di atas, dapat disimpulkan bahwa PLAS adalah salah satu pendekatan dalam pembelajaran yang berorientasi dan berlangsung di lingkungan alam sekitar dengan menggunakan atau memanfaatkan fasilitas-fasilitas yang ada lingkungan alam sekitar sebagai sumber belajar.

Langkah yang harus ditempuh dalam mengaplikasikan metode observasi pembelajaran di luar kelas menurut Vera (2012:137-140) antara lain: (1) menetapkan tujuan pembelajaran, objek, alat dan instrumen yang dibutuhkan dalam observasi, termasuk memperkirakan risiko-risiko yang bisa muncul ketika observasi, (2) menuju 
ke tempat observasi yang telah ditentukan, (3) pengamatan terhadap objek observasi dan dibimbing oleh guru yang mendampingi, (4) penjelasan tentang objek yang diamati, (5) uji pemahaman siswa, (6) penyusunan laporan, serta (7) pembahasan hasil laporan.

Sedangkan menurut Barlia (2006:46) langkah penerapan PLAS dengan metode field trip antara lain: (1) survey lokasi, (2) menentukan objek/titik fokus kegiatan, tujuan pembelajaran, dan petunjuk kegiatan, (3) siswa dibagi menjadi beberapa kelompok, (4) melakukan investigasi dan diskusi pemecahan masalah di alam (akan lebih baik jika disertai dengan beberapa permainan), (5) kembali ke kelas dan melaporkan hasil kegiatan dan temuan.

Berdasarkan beberapa pendapat mengenai langkah-langkah penerapan PLAS maka dapat disimpulkan bahwa langkah-langkah penerapan PLAS antara lain: (1) menentukan tujuan pembelajaran, alat dan instrumen yang dibutuhkan, serta petunjuk kegiatan, (2) siswa dibagi menjadi beberapa kelompok, (3) menuju ke tempat observasi yang telah ditentukan, (4) investigasi dan pengamatan terhadap objek, mendiskusikan lembar tugas, dan mencatat informasi, (5) melaporkan hasil temuan, (6) kesimpulan dan evaluasi pembelajaran.

Berdasarkan uraian di atas, maka dapat disimpulkan bahwa PLAS adalah pendekatan pembelajaran yangberorientasi dan berlangsung di lingkungan alam sekitar dengan menggunakanatau memanfaatkan fasilitas-fasilitas yang ada lingkungan alam sekitar sebagaisumber belajar dengan langkah-langkah sebagai berikut: (1) menentukan tujuan pembelajaran, alat dan instrumen yang dibutuhkan, serta petunjuk kegiatan, (2) siswa dibagi menjadi beberapa kelompok, (3) menuju ke tempat observasi yang telah ditentukan,(4) investigasi dan pengamatan terhadap objek, mendiskusikan lembar tugas, dan mencatat informasi, (5) melaporkan hasil temuan, (6) kesimpulan dan evaluasi pembelajaran.

\section{B. Konsep Keterampilan Proses}

Maslichach (2007: 22) yang menyatakan bahwa keterampilan proses yang perlu dilatih dalam proses belajar mengajar IPA meliputi keterampilan proses dasar misalnya mengamati, mengukur, mengkalisfikasikan, mengkomunikasikan, mengenal hubungan ruang dan waktu, serta keterampilan proses terintergrasi misalnya merancang dan melakukan eksperimen. Sedangkan menurut Samatowa (2010: 137) "Keterampilan proses sains merupakan keterampilan intelektual yang dimiliki dan digunakan oleh para ilmuwan dalam meneliti fenomena alam". Selain itu Indrawati (Trianto 2011: 72) menyatakan "Keterampilan proses merupakan keseluruhan keterampilan ilmiah yang terarah (baik kognitif maupun psikomotor) yang dapat digunakan untuk menemukan suatu konsep, prinsip atau teori untuk mengembangkan konsep yang telah ada sebelumnya, ataupun untuk melakukan penyangkalan kata terhadap suatu penemuan". Sehingga dapat ditarik kesimpulan bahwa keterampilan proses sains merupakan keterampilan intelektual dan ilmiah baik kognitif maupun psikomotor yang digunakan para ilmuwan untuk meneliti dan melakukan penyelidikan ilmiah.

Melalui

keterampilan proses sains ini siswa diharapkan dapat mengalami proses sebagaimana yang dialami para ilmuan dalam memecahkan misteri-misteri alam dan akan menjadi roda penggerak penemuan, pengembangan fakta dan konsep serta penumbuhan dan pengembangan sikap, wawasan dan nilai.

Lebih lanjut lagi, Hamalik (2011: 150) mengemukakan bahwa ada 7 jenis kemampuan yang hendak dikembangkan melalui proses pembelajaran berdasarkan pendekatan keterampilan proses yaitu (1) mengamati, (2) menggolongkan, (3) menafsirkan, (4) meramalkan, (5) menerapkan, (6) merencanakan penelitian, (7) mengkomunikasikan. Sedangkan Kinasih dan Sayekti (2017: 99) menjabarkan bahwa terdapat dua macam KPS, yaitu keterampilan proses dasar dan keterampilan proses 
terintegrasi. Keterampilan proses dasar meliputi mengamati, mengklasifikasi, mengkomunikasikan, mengukur, menyatakan hubungan ruang dan waktu, menggunakan gambar, menginferensi dan memprediksi. Sedangkan, keterampilan proses terintegrasi meliputi mengidentifikasi masalah, mengidentifikasi dan mengontrol variabel, memformulasi hipotesis, menginterpretasi data, mendefinisi operasional, membaca grafik dan melakukan percobaan.

Pada penelitian ini, keterampilan proses sains dibatasi pada keterampilan proses dasar, yang meliputi keterampilan mengobservasi, mengklasifikasi, memprediksi, menyimpulkan, dan mengkomunikasikan.

\section{Penerapan PLAS untuk Meningkatkan Keterampilan Proses pada Siswa Sekolah Dasar}

Proses pembelajaran IPA melalui penerapan PLAS dilaksanakan dengan langkah-langkah sebagai berikut: (1) menentukan tujuan pembelajaran, alat dan instrumen yang dibutuhkan, serta petunjuk kegiatan, (2) mengelompokkan siswa menjadi beberapa kelompok, (3) menuju ke tempat observasi, (4) melakukan investigasi dan pengamatan terhadap objek, mendiskusikan lembar tugas, serta mencatat informasi, (5) melaporkan hasil temuan, serta (6) kesimpulan dan evaluasi pembelajaran. Langkah tersebut sesuai dengan pendapat Sudjana dan Rivai (2015: 214), Vera (2012: 137-140), dan Barlia (2006: 46). Adapun hasil observasi impelementasi PLAS ditunjukan dalam tabel berikut:

Tabel 1 Perbandingan Hasil Observasi Penerapan PLAS

\begin{tabular}{lcccc}
\hline & \multicolumn{3}{c}{ Observasi Guru (\%) } & Rata-rata \\
\cline { 2 - 4 } & Pertemuan 1 & $\begin{array}{c}\text { Pertemuan } \\
\text { (\%) }\end{array}$ & Pertemuan 3 & \\
\hline Siklus I & 71.99 & 79.40 & 81.14 & 77.51 \\
Siklus II & 84.84 & 88.31 & 91.61 & 88.25 \\
\hline
\end{tabular}

Berdasarkan hasil observasi yang telah dilaksanakan, dapat diketahui bahwa terjadi peningkatan terhadap langkah penerapan PLAS di setiap siklus. Capaian guru dalam mengajar siklus I yaitu $77.51 \%$ sedangkan capaian siswa dalam pembelajaran yaitu $73.1 \%$. Hasil tersebut belum mencapai target yang ditentukan. Hal ini dikarenakan terdapat langkah yang belum terlaksana yaitu menyampaikan petunjuk kegiatan observasi. Siswa kurang memperhatikan saat guru menyampaikan petunjuk kegiatan observasi dikarenakan sibuk mempersiapkan diri untuk pembelajaran di luar kelas sehingga keterampilan proses observasi belum maksimal karena banyak siswa yang belum fokus dan bertanya mengenai kegiatan dan petunjuk mengobservasi objek.

Pembelajaran pada siklus I, pada langkah pembagian kelompok dan menuju ke tempat observasi, belum nampak adanya keterampilan proses sains. Langkah selanjutnya yaitu investigasi dan pengamatan objek, mendiskusikan lembar tugas, serta mencatat informasi sudah berjalan dengan baik walaupun hanya beberapa siswa yang mengerjakan lembar tugas sedangkan yang lain bermain sendiri. Siswa telah melakukan kegiatan mengklasifikasikan berbagai jenis hewan berdasarkan bentuk gigi, bentuk kaki, bentuk paruh, dan makanan. Selain itu, pada diskusi kelompok siwa mengerjakan LKS dengan memprediksi mengenai bentuk penyesuaian diri makhluk hidup yang mereka temui dengan bimbingan guru.

Pada langkah melaporkan hasil temuan, siswa terlihat belum percaya diri, raguragu dalam mengkomunikasikan hasil diskusi kelompoknya serta tidak ikut menyimpulkan hasil diskusi LKS bersama guru dan kurang memperhatikan penyampaian tanggapan terhadap presentasi. Sama halnya seperti langkah kesimpulan dan evaluasi, siswa cenderung diam dan tidak mengeluarkan pendapat 
saat ditanya oleh guru. Siswa tidak berpartisipasi aktif dalam menyimpulkan materi pembelajaran. Muijs dan Renold (2008:67) menjelaskan lebih lanjut mengenai keefektifan menjawab pertanyaan yaitu dengan menjawab pertanyaan murid dapat mengklarifikasikan pemikiran dan pemahaman mereka tentang konsep yang diajarkan, dan membuat mereka memverbalisasikan pikiran mereka. Pada langkah ini, belum nampak adanya keterampilan proses sains.

Pembelajaran pada siklus II, semua langkah sudah diterapkan dengan sangat baik sesuai dengan skenario dan RPP. Capaian guru pada siklus II meningkat menjadi 88.74\%, sedangkan capaian siswa meningkat menjadi 85.39. Hasil tersebut sudah mencapai target yang ditentukan sehingga penelitian dapat dihentikan. Pada langkah pertama yaitu menentukan tujuan pembelajaran, alat dan instrumen yang dibutuhkan, serta petunjuk kegiatan. Siswa memperhatikan penjelasan guru mengenai tujuan pembelajaran dan petunjuk observasi. Dengan memperhatikan penjelasan guru, akan menujang siswa dalam mengobservasi tumbuhan atau hewan yang merupakan materi pokok kelompok untuk dipresentasikan.

Pada langkah selanjutnya, yaitu langkah investigasi dan pengamatan terhadap objek, mendiskusikan lembar tugas, dan mencatat informasi. Pada langkah ini, siswa dengan bimbingan guru mengklasifikasikan tumbuhan dan hewan berdasarkan bentuk penyesuaian dirinya. Kemudian siswa menginvestigasi sekaligus memprediksi bentuk penyesuaian diri makhluk hidup pada kegiatan bertanya jawab dengan guru. Setelah mendapatkan informasi, siswa mendiskusikan tugas dan mencatat informasi berdasarkan fakta yang siswa dapat pada kegiatan observasi dan investigasi.

Pada langkah melaporkan hasil temuan, keterampilan proses yang terlihat adalah keterampilan mengkomunikasikan. Menurut pendapat Desstya (2015: 97) keterampilan mengomunikasikan merupakan keterampilan untuk menyampaikan hasil penemuannya kepada orang lain, dalam bentuk laporan penelitian, membuat paper atau menyusun karangan. Pada langkah ini, keterampilan komunikasi siswa meningkat. Siswa dapat mempresentasikan hasil diskusi kelompoknya di depan objek observasi dengan menunjukkan data-data yang mereka dapatkan sehingga teori yang telah diperoleh dari guru dapat mereka buktikan. Setiap kelompok siswa mendapatkan materi yang berbeda sehingga siswa mendapatkan banyak data dan informasi mengenai bentuk penyesuaian diri makhluk hidup. Partisipasi siswa dalam menanggapi presentasi kelompok lain juga meningkat, selain itu siswa percaya diri dalam menanyakan dan membenarkan hasil diskusi kelompok lain yang kurang tepat. Siswa juga aktif menyampaikan gagasan maupun ide saat pembelajaran berlangsung.

Pada langkah terakhir yaitu kesimpulan dan evaluasi. Siswa berpartisipasi aktif dalam menyimpulkan materi pembelajaran dengan bimbingan guru. Hal ini dikarenakan guru mulai memberikan pertanyaan-pertanyaan yang terkait dengan kesimpulan diskusi dan materi pembelajaran untuk mengaktifkan siswa. Muijs dan Renold (2008:67) menjelaskan lebih lanjut mengenai keefektifan menjawab pertanyaan yaitu dengan menjawab pertanyaan murid dapat mengklarifikasikan pemikiran dan pemahaman mereka tentang konsep yang diajarkan, dan membuat mereka memverbalisasikan pikiran mereka.

Berdasarkan penjelasan pelaksanaan langkah penerapan PLAS pada siklus I, dan II dapat disimpulkan adanya peningkatan keterampilan proses sains dalam pembelajaran. Peningkatan terjadi karena selalu dilakukan perbaikan di setiap pertemuan sehingga keterampilan proses meningkat.

\section{SIMPULAN}

Berdasarkan pembahasan tentang konsep dan implementasi PLAS pada pembelajaran IPA di SDN 2 Karangreja Kabupaten Purabalingga, terdapat kesimpulan sebagai berikut: 
1. PLAS adalah pendekatan pembelajaran yang berorientasi dan berlangsung di lingkungan alam sekitar dengan menggunakanatau memanfaatkan fasilitasfasilitas yang ada lingkungan alam sekitar sebagai sumber belajar. Penerapan PLAS menggunakan langkah-langkah sebagai berikut: (1) menentukan tujuan pembelajaran, alat dan instrumen yang dibutuhkan, serta petunjuk kegiatan; (2) siswa dibagi menjadi beberapa kelompok; (3) menuju ke tempat observasi yang telah ditentukan; (4) investigasi dan pengamatan terhadap objek, mendiskusikan lembar tugas, dan mencatat informasi; (5) melaporkan hasil temuan; (6) kesimpulan dan evaluasi pembelajaran.

2. Keterampilan proses sains merupakan keterampilan intelektual dan ilmiah baik kognitif maupun psikomotor yang digunakan para ilmuwan untuk meneliti dan melakukan penyelidikan ilmiah sehingga diharapkan siswa dapat mengalami proses sebagaimana yang dialami para ilmuan dalam memecahkan misteri-misteri alam dan akan menjadi roda penggerak penemuan, pengembangan fakta dan konsep serta penumbuhan dan pengembangan sikap, wawasan dan nilai.

3. Penerapan PLAS dapat meningkatkan keterampilan proses sains yaitu keterampilan mengobservasi, mengklasifikasi, memprediksi, menyimpulkan, dan mengkomunikasikan.

\section{DAFTAR PUSTAKA}

Samatowa, U. (2006). Bagaimana Membelajarkan IPA di Sekolah Dasar. Jakarta: Departemen Pendidikan Nasional Direktorat Jenderal Pendidikan Tinggi Direktorat Ketenagaan.

Isnanto, H. (2016). Penerapan Pendekatan Alam Sekitar untuk Meningkatkan Keterampilan Proses IPA dan Sikap IImiah Pada Siswa Kelas V di SD Negeri GedongTengen Yogyakarta. Jurnal Pendidikan Guru Sekolah Dasar, 5 (29): 2.758-2.760.

Desstya, A. (2015). Keterampilan Proses Sains dan Pembelajaran IPA di Sekolah Dasar. Profesi Pendidikan Dasar, 2(2): 95-102.

Barlia, L. (2006). Mengajar Dengan Pendekatan Lingkungan Alam Sekitar (PLAS). Jakarta: Departemen Pendidikan Nasional.

Vera, A. (2012). Metode Mengajar Anak di Luar Kelas (Outdoor Study). Yogyakarta: Diva Press.

Gilchrist, M., Passy, R., Waite, S. \& Cook, R. (2016).Exploring Schools Use of Natural Spaces. Dalam Freeman, C. \& Tranter, P. (Eds), Risk, Protection, Provision and Policy Volume 12 of Skelton, T. (ed)Geographies of Children and Young People. (hlm. 6). Singapore: Springer.

Sudjana, N. \& Riva'i, A. (2015). Media Pengajaran. Bandung: Penerbit Sinar Baru Algesindo.

Trianto. (2011). Model Pembelajaran Terpadu Konsep, Strategi, dan Implementasinya dalam Kurikulum Tingkat Satuan Pendidikan (KTSP). Jakarta: PT Bumi Aksara.

Maslichach, A. (2007). Penerapan Pendekatan Sains-Teknologi Masyarakat dalam Pembelajaran Sains di Sekolah Dasar. Yogyakarta: Universitas Sanata Dharma.

Muijs, D. dan Reynolds, D. (2008). Effective Learning Teori dan Aplikasinya. Yogyakarta: Pustaka Pelajar.

Hamalik, O. (2011). Kurikulum dan Pembelajaran. Jakarta : Bumi Aksara. 